\title{
Introduction: Dynamics of the Social Construction of East Asia
}

\section{CHIN YEE WHAH}

The multifarious forces of globalization have profoundly changed not only the global economic landscape but also the identities of ethnic groups, nations and regions. As highlighted in the four articles that constitute this special issue, globalization has led to increasing cooperation between East and Southeast Asian countries through the simultaneous processes of regionalization and regionalism. Each country contributes to closer cooperation in Asia, albeit unevenly and in different ways (Frost 2008: 14). Since the 1990s, regionalism has been viewed as a potent force in the globalization process as 'it represents concentrations of political and economic power competing in the global economy, with multiple inter-regional and intra-regional flows' (Mittelman 1996: 190). This powerful force is extended into cross-regional inter-state cooperation in terms of seeking preferential trading relations with countries outside the region through free trade agreements (Solis and Katada 2007). The current trend leans towards establishing more extensive and multifaceted external linkages within a multipolar context.

The ASEAN Six (Philippines, Thailand, Indonesia, Malaysia, Singapore and Brunei) and CLMV (Cambodia, Laos, Myanmar and Vietnam) countries have very diverse historical, cultural, social, economic and political backgrounds. These 10 ASEAN countries registered relatively high economic growth in 2012 (OECD Development Centre 2013: 2) ${ }^{1}$ compared to other parts of the world, such as North America and the Eurozone. The dynamics of region-building are demonstrated in the inclusion of China, South Korea and Japan, countries that are culturally and historically separated from Southeast Asia, to form ASEAN plus Three (APT). Regional integration is a growing concern, and is focused on achieving the ASEAN Economic Community (AEC) by 2015. ${ }^{2}$ The AEC is deepening regional economic integration with the adoption of more common policies among member countries (Wesley 2003), which will transform ASEAN into a region with free movement of merchandise, services, investment and skilled labour, as well as a freer flow of capital.

In the larger East Asia region, the concept of an East Asian Community (EAC) is developing, and now includes the ASEAN plus Three 
and two Newly Industrialised Economies (NIEs), namely Taiwan and Hong Kong. The dramatic economic growth of China has stimulated the formation of an EAC that constitutes a huge consumer market, with about 20 per cent of the world's GDP, about half of the world's total foreign exchange reserves and rapid economic growth. These points indicate that the EAC is not only important to the region, but is also significant to world prosperity (Wong and Yang 2006). This new drive towards integration and 'community building' driven by multiple state actors is perceived as Asia's 'new regionalism'.

Regionalism and the processes of regionalization involved multiple state- and non-state actors engaging in cross-border economic activities: integrating markets, financial systems, technology, society and labour. Regionalization is powered by business strategies used by powerful global enterprises or multinational corporations, which create (and recreate) new concepts of political framework or ideas that enhance regionalised and globalised economic transactions (Spindler 2002: 4-5). On the other hand, besides states, powerful actors engaging in dialogue about the depth and direction of regionalism form an epistemic community. ${ }^{3}$ Members of transnational epistemic communities can have direct or indirect influence over state interests in international negotiations and policy coordination involving trade, security and other matters (Haas 1996: 4-5), thereby constructing an identity that represents one specific region (Sindler 2002: 7). Actors with powerful connections are involved in these processes (Frost 2008: 14-15) that shape the direction and speed of integration, create cultural diversity and transform identities. The twin-processes of regionalism and regionalization do not suppress civil society; rather they create the potential for forming regionalized civil societies that combine with local conditions in distinctive ways (Mittelman 1996: 196-197).

Attempts at nation building and the integration of diverse segments of a society in pursuit of creating a homogenous national identity remain challenging for ethnically heterogeneous states. Conversely, preservation of national ideology in more homogenous states such as Japan may take a different path, protecting their cultures, ideologies and work ethics from being tainted by foreign influences. Other ethnically homogeneous states, such as South Korea, attempt to construct their national identities by embracing globalization. Kenji Kaneko's article in this volume discusses Japan, which has a strong national identity and relatively homogeneous culture and which is very careful in its immigration policy vis-à-vis foreign labour. This measure aims to protect 
Japan's traditional culture and identity in the context of global labour integration. Conversely, Jojin John discusses South Korea, which has a strong national identity and is engaging globalization to improve its global status, standard of living, and political influence through the 'soft power' of its Global Korea foreign policy.

The forces of globalization also create complex identities in social realms, where a confluence of migrant labourers from various national and ethnic backgrounds meet in workplaces and markets. This impacts upon societies in unpredictable ways and goes beyond a state's capacity to effectively manage nation building. Ron Bridget Vilog's article explores the creation and re-creation of ethnic borders, taking the example of the situation of Filipino migrant workers for whom regional identities are reinforced in the context of labour integration beyond nation-state borders.

This special issue identifies some of the major observable forces of globalization that have affected enterprises and societal change within East and Southeast Asia. The contributors each try to understand how connectivity, through the compression of time and space, shapes enterprise strategies, labour movements and identities within and beyond state boundaries. Each article in its own way examines the relative positions of state and non-state actors in engaging the forces of globalization to preserve or enhance competitiveness, longevity and nationhood.

The first article, by Benny Teh, provides a detailed analysis of the dynamic interactions between state (formal and political) and nonstate (informal and economic) actors that shape the scope and pace of East Asian regionalism and regionalization, as exemplified in political frameworks such as the ASEAN 10, ASEAN plus Three, the East Asia Summit (EAS) and the ASEAN Regional Forum (ARF). The article views regionalism as a process, a formal regionalist project led by state actors. Conversely, regionalization is regarded as a process determined by informal initiatives and driven by non-state actors. By connecting the formal and informal realms, Benny Teh identifies various aspects of the social construction of East Asia and provides an understanding of how states, markets and epistemic communities interact in region building. The article highlights the shift from ASEAN's original objectives as a security organization towards its current focus on economic integration. However, various cooperative schemes proposed by member countries show that national priorities are still prioritized over regional interests. The paper describes the connectivity and cross-level interaction between state and economic actors through regional schemes such as Brand-to- 
Brand Complementation (BBC), ASEAN Industrial Cooperation (AICO) and ASEAN Investment Area (AIA). BBC was initiated by non-state actors (automotive industry players) and aims to facilitate economic regionalization. AICO, which replaced the BBC in 1996, and the ASEAN Industrial Complementation (AIC), has a broader scope that promotes industrial complementation and aims to stimulate intra-regional trade and inward investment. The AICO scheme, which favours local firms and economies by imposing regulations on foreign multinational corporations in the ASEAN region, presents contradictions between state-led regionalism and economic regionalization. In contrast, the AIA, which is a state-led regional initiative, aims to increase investment inflow and intra-regional trade but prioritizes protection of national interests. Through an analysis of these schemes, the article points out the tensions between state notions of regionalism and economic interests in regionalization. Another tension between state and non-state interests among member countries is states' pursuit of bilateral trade pacts that leave business actors and civic groups out of the negotiations. Such issues may affect the progress of region construction. Finally, the article addresses the role of epistemic communities in the social construction of East Asia. Epistemic communities are represented in local, regional and international institutions. The ASEAN Institutes of Strategic and International Studies (ASEAN-ISIS) and the Network of East Asian Think-Tanks (NEAT) are two significant regional networks in East Asia that have the ability to exert influence over the shape of East Asian regionalism. Benny Teh argues that differences do arise when epistemic actors engage state actors in discussions of region building.

Jojin John's article discusses South Korea's national identity building project. South Korea is an advanced nation influenced by globalization, as exemplified in its 'Global Korea' foreign policy. The article connects globalization, national identity and foreign policy to the discourse of seonjinguk (advanced nation) status in international affairs. John establishes the connection between globalization and the dynamism of Korean national identity by describing the evolution and transformation of Korea's foreign policy focus under different administrations. He argues that the discourse of seonjinguk is a historically constructed knowledge system, which has become an ideal image for the transformation of the Korean society. The article traces the evolution of the discourse of seonjinguk through an analysis of slogans that have featured in Korea's foreign policies, such as guendaewa (modernisation), which was prominent from the early 1960s until the mid-1980s, segyehwa (globalization) 
during the 1990s and seonjinwa (achieving advancement) since the late 2000s. Elites in South Korea embrace globalization as the way forward to achieving global standards in all aspects of peoples' lives and becoming a fully advanced country. The adoption of segyehwa is a call for a fundamental transformation, reaching beyond the spheres of economy and technology and into every aspect of Korean public and foreign policy. Segyehwa has become Korea's 'new diplomacy' and a means to achieve seonjinguk identity; it has gained wide public support and is manifest in South Korea's membership of international organizations such as the United Nations (UN), Organisation for Economic Cooperation and Development (OECD), intergovernmental organizations (IGO) and the World Trade Organisation (WTO). Since 2008, the discourse for achieving the seonjinguk status has shifted away from the role of the state towards investigating how private actors and market forces can sustain South Korea's position as an economic power. National branding, like the 'Global Korea' slogan coined in 2008, diplomacy and holding high profile international meetings are all utilised to achieve the desired identity, arguably an ideological shift from a nationalist to a globalist interpretation of Korean identity.

Ron Bridget Vilog's article highlights the fluidity and dynamics of identity construction among the Filipino nikkeijin (in this case, the descendants of Japanese emigrants to the Philippines who subsequently returned to Japan) working in Japanese production plants in Aichi Prefecture, Japan. Vilog's analysis is framed in the context of cultural and economic globalization. The Filipino nikkeijin in this study identify themselves as genuine Filipinos despite being born, raised and educated in Japan; the diasporic social environment of their family and kin members in Japan helps them maintain their identity as Filipinos; and they are emotionally connected to the Philippines. He argues that these elements create an exclusive grouping that unifies Filipino nikkeijin, who exhibit a kind of 'deterritorialized nationalism', not least when they support each other in the multi-ethnic workplace. This sense of shared identity is situational; it becomes apparent when Filipino nikkeijin sympathise with their compatriots in times of distress. However, according to Vilog, there is a further level of 'locality' found in the workplace, based on ethnic stereotyping that underlies regional solidarities among groups like the Bisayan, Ilocano, Tagalog, Kapampangan and Bicolano. In addition, there are power plays and politics that erupt between these smaller groups within the kaisha (company or corporation), causing fragmentation and conflict among the Filipino nikkeijin. It concludes that the Filipino nikkeijin community 
has failed to fully integrate into the social and political levels of Japanese society, arguing that 'migration as an offshoot of globalization has successfully weakened the dogma of national sovereignty, yet it supports the multiplicity of identities' (Vilog, this volume).

The final article, by Kenji Kaneko, discusses the incorporation of migrant workers from Southeast Asia into Japan's healthcare industry. This is a result of bilateral free trade agreements signed between Japan-Indonesia (July 2008), Japan-the Philippines (November 2004) and Japan-Vietnam (December 2008). The inflow of foreign migrants into Japan is perceived as an ideological threat to Japan's homogeneity among Japanese conservative nationalists, business elites and other influential groups. Kaneko discusses the longstanding debate among policy-makers and scholars over whether Japan should sakoku (close the country) or kaikoku (open the country). The sakoku faction claims that the presence of foreign migrants taints Japan's cultural purity and work ethic, and that it disrupts social harmony. This is based on the assumption that Japan, as a unique and culturally homogeneous society (nihonjinron), has no tolerance for foreigners. Conversely, the kaikoku faction leans more towards globalization, considers Japan as part of the international community and is consequently more relaxed in its immigration policy proposals. Following the sakoku line, the government has developed strict guidelines on how to select foreign nurses and caregivers. Candidates for these roles have to pass a Japanese language based examination to attain Japanese-standard certification. Despite this, under the Japan-Indonesia Economic Partnership Agreement (JIEAP), when 362 healthcare worker candidates arrived from Indonesia in 2008, they faced a multitude of difficulties in hospitals and retirement homes. Japanese healthcare workers, patients and their family members were reluctant to accept the foreign workers because of cultural differences and communication problems. The article concludes, however, that the inclusion of Southeast Asian healthcare workers in Japan has had no major impact on Japanese society. Instead, this inclusion has stimulated further discussions of Japanese identity, position in the world and attitude towards globalization.

In short, this special issue identifies some of the major global and regional forces that have shaped societal changes in East Asia. It analyses the interactions of the various actors-including states, enterprises, epistemic communities, migrant workers, local communities and the media-that contribute to the dynamics of the social construction of East Asia in the context of globalization. 
Chin Yee Whah is Associate Professor at the School of Social Sciences, Universiti Sains Malaysia. His research interests include Chinese business, family business, entrepreneurship, business partnership, knowledge management and trading networks. Email: ywchin@usm.my

\section{NOTES}

1 OECD 2013. Economic Outlook for Southeast Asia, China and India 2014: Beyond the Middle-Income Trap. OECD Development Centre. www.oecd.org/site/seao/Pocke $\mathrm{t} \%$ 20Edition\%20SAEO2014.pdf. Accessed 1 May 2015.

2 The AEC is a work in progress. Most high-priority goals needed for implementation have been met but the full benefits of AEC in terms of economy, social and trade for the ASEAN region have yet to be realized completely. See http:/ / thediplomat. com/2015/05/the-asean-economic-community-a-work-in-progress/. Accessed 9 November 2015.

3 An epistemic community is a network of professionals from a variety of disciplines and backgrounds, with recognized expertise and competence in a particular domain and an authoritative claim to policy-relevant knowledge within that domain or issue-area (Haas 1992: 3).

\section{REFERENCES}

Frost, Ellen L. 2008. Asia's New Momentum. In E.L. Frost (ed.) Asia's New Regionalism. Boulder, Colorado: Lynne Reinner: 1-20.

Haas, Peter M. 1992. 'Introduction: Epistemic Communities and International Policy Coordination'. International Organization 46(1): 1-35.

Mittelman, James H. 1996. "'New Regionalism" in the Context of Globalization'. Global Governance 2(2): 189-213.

Solis, Mireya and Soari K. Katada 2007. 'Introduction: Understanding East Asia CrossRegionalism: An Analytical Framework'. Pacific Affair 80(2): 229-257.

Spindler, Manuela 2002. New Regionalism and the Construction of Global Order. CSGR Working Paper No. 39/02. University of Warwick, United Kingdom.

Wesley, Michael 2003. Membership Expansion and Change. In M. Wesley (ed.) The Regional Organisations of the Asia Pacific: Exploring Institutional Change. Basingstoke, Hampshire: Palgrave Macmillan: 97-116.

Wong, John and Yang Zhang 2006. 'China as Catalyst for East Asian Economic Cooperation'. In P.P. Lee, S.Y. Tham and G.T. Yu (eds.) The Emerging East Asian Community: Security and Economic Issues. Bangi: Penerbit Universiti Kebangsaan Malaysia: 267-285. 